\title{
ИЗМЕНЕНИЯ СТРУКТУРЫ РОЗНИЧНОЙ ТОРГОВЛИ ПЯТОЙ АВЕНЮ Г. НЬЮ-ЙОРКА В УСЛОВИЯХ ФОРМИРОВАНИЯ ЦИФРОВОЙ ЭКОНОМИКИ
}

\author{
(c) 2019 Теванян Анна Михайловна \\ аспирант кафедры мировой экономики \\ Дипломатическая академия Министерства иностранных дел Российской Федерации, \\ Россия, Москва \\ E-mail: ladyanna4@yandex.ru
}

\begin{abstract}
Статья посвящена исследованию изменений в структуре ритейла Пятой авеню г. Нью-Йорка в условиях формирования цифровой экономики. Актуальность темы обусловлена необходимостью изучения ряда аспектов, наблюдаемых в результате трансформации розничной торговли Пятой авеню, таких как закрытие магазинов традиционного торгового формата и развитие инновационных форматов торговли, совмещающих цифровые сервисы и традиционную розничную торговлю (гибридных). Авторами были поставлены и решены следующие задачи: проанализирована текущая тенденция закрытия магазинов традиционного формата Пятой авеню и рассмотрены причины ее возникновения; исследованы экономические показатели развития г. Нью-Йорка, влияющие на ритейл; выявлены и изучены актуальные изменения торговой структуры на Пятой авеню в условиях формирования цифровой экономики; рассмотрено развитие «гибридных форматов торговли». Направления дальнейшего исследования видятся в изучении вопроса развития гибридных форматов торговли со стороны исследователей и практиков отечественного рынка с целью предотвратить проблемы, возникающие с развитием цифровизации ритейла, и адекватно имплементировать накопленный положительный опыт США в их решении.
\end{abstract}

Ключевые слова: розничная торговля, гибридный формат торговли, США, пятая авеню, электронная коммерция, цифровизация.

Введение. «Смерть розничной торговли»термин, который, согласно сервису «Google Trends», появился в 2009 г. и затем был предложен к обсуждению экспертному сообществу [1]. Позднее, в 2017 г., в Википедии была создана тематическая страница с куда более эмоциональным названием - «Апокалипсис ритейла», описывающим более прагматично современные тенденции, наблюдаемые в секторе традиционной розничной торговли США [2].

В действительности, за последние годы в американском ритейле произошли существенные изменения, особенно заметные по многим ранее доминировавшим на рынке торговым предприятиям: «Sears», «Radio Shack», «JCPenney», «Circuit City» и ряду торговых центров, которые сегодня изо всех сил пытаются приспособиться к конкурентной среде [3]. За прошедшие в 20182019 гг. новогодние праздники в США продажи универмагов традиционного формата снизились на 1,3\% по сравнению с предыдущим годом, в то время как показатель общих розничных продаж вырос на 5,1\% [4]. Растущая конкуренция оказывает значительное давление на торговые сети американских универмагов, а катализатором в этом процессе выступают покупатели, которые в условиях формирования цифровой экономики становятся все более привержены к интернетшоппингу и новым форматам торговли, сочетающем традиционные и цифровые инструменты продаж.

Город Нью-Йорк, когда-то считавшийся оплотом розничной торговли, теперь все больше ощущает деструктивные последствия замедления темпов традиционной розницы. Многие американские СМИ сообщают, что Пятая авеню, расположенная в Манхэттен боро (амер. Borough - один из пяти районов г. Нью-Йорке, а также город средней величины с определенным статусом и привилегиями), занимавшая почти пять лет верхнюю строчку в рейтинге самых дорогих торговых улиц в мире, теперь «пестрит» пустыми витринами и объявлениями о доступных для аренды торговых площадях.

По данным ежегодного рейтинга самых дорогих улиц мира, Пятая авеню в 2018 г. оказалась на втором месте с размером средней арендной ставки 2,25 тыс. долл. США за кв. фут в год, усту- 
пив лидирующую позицию улице Козуэй-Бей Гонконга. В то время, как еще в 2017 г., она была первой в топе, с размером арендной ставки -3 тыс. долл. США за кв. фут в год [5].

Некоторые американские СМИ назвали тенденцию упадка розничной торговли «чумой пустых витрин» Нью-Йорка, в то время как существует и другое мнение о том, что «кризис недвижимости ритейла, пустующей без арендаторов» надуман. Так или иначе, изменения структуры и показателей розничной торговли Пятой авеню обусловлены продолжающимся по всей стране спадом розничной торговли традиционного формата, поворотом покупательского интереса в сторону цифровых форматов торговли и рядом других причин, безусловно, требующих детального анализа.

Цель и задачи исследования. В научной литературе исследования на тему изменений структуры розничной торговли Пятой авеню г. Нью-Йорка практически отсутствуют. В этой связи целью данного исследования стало рассмотрение и обобщение имеющихся данных об актуальных изменениях, происходящих в секторе розничной торговли Пятой авеню г. НьюЙорка в условиях формирования цифровой экономики. В работе были поставлены и решены следующие задачи: исследованы экономические показатели развития г. Нью-Йорка, влияющие на ритейл; проанализирована текущая тенденция закрытия магазинов традиционного формата Пятой авеню и рассмотрены причины ее возникновения; выявлены и изучены актуальные изменения торговой структуры на Пятой авеню в условиях формирования цифровой экономики. Методика исследования базируется на обобщении и анализе имеющегося теоретического материала американских научных исследований и мнений экспертного сообщества, изучающего практическую сторону вопроса, а также на консолидации материалов ранее выполненных зарубежных исследований, систематизации и группировки полученных данных.

Полученные результаты. По итогам 2018 г. экономические показатели г. Нью-Йорка продолжают демонстрировать здоровый рост. Так, показатель уровня занятости населения с 2017 г. вырос почти на 68 тыс. рабочих мест, достигнув отметки 4,5 млн. в ноябре 2018 г. [6]. В целом за год, с декабря 2017 г. по декабрь 2018 г., уровень занятости населения увеличился на 9\% [7].

Однако, за период с октября по декабрь 2018 г., уровень занятости в розничной торговле демонстрирует спад. Так, в октябре этот показатель составил приблизительно 357 тыс. лиц, занятых в этом секторе, в ноябре он снизился на 1,8 тыс. рабочих мест (р.м.) по сравнению с предыдущим месяцем [8] и составил около 356 тыс.р.м., в декабре снизился на 1,7 тыс.р.м. и составил 354 тыс.р.м. [7].

За 2017 г. с 1-4 кварталы изменения показателя уровня розничных продаж по США по отношению к соответствующим кварталам 2016 г. составили: 5,2\%, 4,3\%, 4,5\% и 5,9\% [6,13,14,15].

В 2018 г. уровень продаж в секторе ритейла Манхэттена вырос на 6,3\% и, по прогнозам, составленным в 4 квартале 2018 г., он вырастет еще на $4.3 \%$ в 2019 г. [6].

Туризм - критически важный драйвер роста активности розничной торговли Нью-Йорка. По состоянию на конец 2018 г., можно констатировать, что количество туристов, посещающих город, уверенно растет: в 2018 г. этот показатель составил - 65,1 млн. людей - и это на 3,7\% больше по сравнению с показателем 2017 г.- 61,8 млн. Покупки и другие денежные траты такого количества посетителей “Большого яблока” из других стран принесли в различные экономические секторы города 13,5 млн. долл. США- на 3,1\% больше, чем в прошлом году [6].

О тенденции закрытия магазинов традиционного торгового формата.

Вопреки положительной динамике рассмо-

Таблица 1. Динамика изменения показателей занятости населения США и г. Нью-Йорка за 2017-2018 гг.

\begin{tabular}{|l|c|c|c|c|c|c|c|c|}
\hline \multicolumn{1}{|c|}{ Показатель } & \multicolumn{4}{|c|}{2017 г. } & \multicolumn{5}{c|}{2018 г. } \\
\cline { 2 - 12 } & 1 кв. & 2 кв. & 3 кв. & 4 кв. & 1 кв. & 2 кв. & 3 кв. & 4 кв. \\
\hline $\begin{array}{l}\text { Уровень занятости и г. Нью-Йорка (млн. } \\
\text { долл. США) }\end{array}$ & 4.4 & 4.4 & 4.4 & 4.5 & 4.5 & 4.5 & 4.5 & 4.5 \\
\hline Уровень безработицы г. Нью-Йорка (\%) & 4.6 & 4.6 & 4.5 & 4.4 & 4.2 & 4.2 & 4.1 & 4 \\
\hline Уровень безработицы США (\%) & 4.7 & 4.3 & 4.4 & 4.1 & 4.1 & 3.8 & 3.9 & 3.7 \\
\hline
\end{tabular}

Источник: составлена авторами на основе данных “Кушман энд Вэйкфилд” квартальных отчетов за 2017-2018 гг. $[9,10,11,12]$. 
Таблица 2. Оценка ежемесячного объема продаж в секторе розничной торговли и общественного питания США за 2017-2018 гг.

\begin{tabular}{|l|c|c|c|c|c|c|c|}
\hline \multirow{2}{*}{$\begin{array}{c}\text { Отрасль согласно } \\
\text { североамериканской } \\
\text { системе классификации } \\
\text { отраслей (NАІСS) }\end{array}$} & \multicolumn{2}{|c|}{ Итого за 12 мес. } & \multicolumn{3}{|c|}{2018 г. } & \multicolumn{2}{|c|}{2017 г. } \\
\cline { 2 - 8 } & 2018 & $\begin{array}{c}\text { \% изм. к } \\
2017 \text { г. }\end{array}$ & $\begin{array}{c}\text { дек. } \\
\text { (а)- } \\
\text { прогно- } \\
\text { зируемая } \\
\text { оценка }\end{array}$ & $\begin{array}{c}\text { нояб. } \\
\text { (р)- } \\
\text { предва- } \\
\text { рительная } \\
\text { оценка }\end{array}$ & $\begin{array}{c}\text { окт. } \\
\text { (r)-уточ- } \\
\text { ненная } \\
\text { оценка }\end{array}$ & дек. & нояб. \\
\hline $\begin{array}{l}\text { Розничная торговля и } \\
\text { общетвенное питание, } \\
\text { всег. }\end{array}$ & 6036420 & 5,0 & 569523 & 524525 & 506963 & 561418 & 499833 \\
\hline $\begin{array}{l}\text { Всего (кроме транспорт- } \\
\text { ных средств и запчастей) }\end{array}$ & 4807302 & 5,5 & 465088 & 426923 & 405661 & 460243 & 404231 \\
\hline $\begin{array}{l}\text { Всего (кроме бензозапра- } \\
\text { вочных станций) }\end{array}$ & 5521386 & 4,3 & 531031 & 482686 & 460021 & 522772 & 461047 \\
\hline $\begin{array}{l}\text { Всего (кроме. транспорт- } \\
\text { ных средств и запчастей, а } \\
\text { также бензозаправочных } \\
\text { станций) }\end{array}$ & 4292268 & 4,6 & 426596 & 385084 & 358719 & 421597 & 365445 \\
\hline \multicolumn{1}{|c|}{ Розничная торговля } & 5320118 & 4,9 & 508508 & 466746 & 446615 & 501921 & 445632 \\
\hline
\end{tabular}

Источник: составлена авторами на основании данных Бюро статистики США (англ. United States Census Bureau, Bureau of the Census) [16].

Примечание № 1: данные представлены без учета сезонных колебаний и праздничных дней.

Примечание № 2: единицы измерения - млн. долл. США.

тренных показателей в структуре розничной торговли и в структуре недвижимости, арендуемой магазинами ритейла на Пятой авеню, с 2017 г. наблюдаются изменения негативного характера. Так, компания «Геп Инк» (англ. Gap Inc.) заявила, что закроет сотни «неэффективных» офлайн магазинов по всей территории США, включая трехэтажный магазин на Пятой авеню Манхэттена [17]. Там же, уже более года пустует «Ральф Лорен Поло» (англ. Ralph Lauren Polo) и с января 2019 г. закрыт «Анри Бендель» (англ. Henri Bendel), люксовый бренд с 123-летней историей существования [18]. Вместе с этим в декабре 2018 г. американский сетевой универмаг «Лорд энд Тейлор» (англ. Lord and Taylor) закрыл свой флагманский магазин, располагавшийся на Пятой авеню с 1914 г. Компания «Хадсон Бей энд Ко» (англ Hudson Bay Co), владеющая сетью универмагов с 2012 г., объясняет такое решение “смещением акцентов в сторону онлайн-продаж и возрастанием интересов развития в области цифровых возможностях торговли» [19].

Безусловно, такая волна закрытий «столпов американской розничной торговли» и привела к росту доступной для аренды торговой недвижимости, рассмотренных в Таблице 3.

Рассматривая изменение показателя доступных торговых площадей субрынков Пятой Авеню за 2018 г., представленное в Таблице 3, можно отметить, что по сравнению с началом года в целом его значение увеличилось. Особенно это заметно по самому дорогостоящему субрынку Пятой авеню - с 49 до 60 ул.

Мнение экспертов о сложившейся кризисной ситуации на рынке разделилось: одни назвали ее «чумой пустых витрин», в то время как другие доказывают, что «кризис вакантных площадей, предназначенных для розничной торговли» надуман. В этих дебатах оказались значимы слова Фейс Хоуп Консоло, председателя «Дуглас Эллиман» (англ. Douglas Elliman), которая заявила, что «в Нью-Йорке доступно/

Таблица 3. Динамика изменения показателя доступных для сдачи в аренду торговых площадей по кварталам за 2018 г.

\begin{tabular}{|l|c|c|c|c|}
\hline \multicolumn{1}{|c|}{ Субрынок Пятой авеню г. Нью-Йорка } & 1 кв. & 2 кв. & 3 кв. & 4 кв. \\
\hline Пятая авеню (от 42 до 49 улицы) \% & 32.8 & 27.6 & 25.9 & 23.3 \\
\hline Пятая авеню (расположение от 49 до 60 улицы) \% & 17.4 & 20.3 & 24.6 & 27.5 \\
\hline Пятая авеню (непосредственное расположение, от 49 до 60 улицы) \% & 8.7 & 10.1 & 10.2 & 14.5 \\
\hline ИТОГО: & 58.9 & 58 & 60.7 & 65.3 \\
\hline
\end{tabular}

Источник: составлена авторами на основании данных “Кушман энд Вэйкфилд” [6,13,14,15]. 
пустуют (англ. vacant - доступно, свободно) 20\% торговых площадей» [20]. Позже она утверждала, что ее неправильно процитировали в «НьюЙорк Таймс», так как 20\% ссылались на доступную сейчас или освобождающуюся в ближайшем будущем торговую площадь (англ. availability), а не на пустующие вакантные позиции (англ. vacancy). Опираясь на номинальную цифру «20\%», со стороны городского совета (англ. City Hall) возникли лоббистские движения в сторону продвижения законопроекта о контроле за арендой недвижимости, предназначенной для размещения розничной торговли.

«Закон о контроле и стабилизации размеров арендной платы в г. Нью-Йорке» (англ. New York's Rent Control and Rent Stabilization Laws), ограничивающий размер арендной платы и обеспечивающий некоторые протекционные меры коммерческих отношений в этой области, не является чем-то новым. Так, в 1945-1963 гг. в городе уже был введен в действие закон, ограничивающий отношения в сфере коммерческой аренды недвижимости, после истечения срока действия которого, такой контроль в муниципальной политике был упразднён. Однако в последние годы, горсовет вновь выступил с инициативой пересмотра коммерческого регулирования арендной платы, изложенной в предложенном им «Законопроекте о поддержании сохранения рабочих мест малого бизнеса» (интро 737) § 22-1202 (англ. Small Business Jobs Survival Act). Ответ Совета по недвижимости Нью-Йорка (англ. The Real Estate board of New York) на такую инициативу был peшительно отрицательным. Совет и другие игроки рынка утверждают, что контроль коммерческой аренды - это не панацея для искоренения проблем рынка розничной торговли, и что его принятие может усугубить проблему, создавая искусственное пресечение интересов и желаний арендодателей в модернизации существующих коммерческих площадей или создании новых для конкурентоспособности на рынке. В частности, «молодые» ритейлеры могут испытывать затруднения с арендой недвижимости, так как ее владельцы будут стремиться избежать обременения от заключения с ними контрактов на длительные сроки [21]. В задачи данного исследования не входило дать обзор законопроекта и практических препятствий и преференций, с которыми рынок столкнётся в случае его принятия, однако, считаем, что эта тема заслуживает отдельного рассмотрения.
В свою очередь, такая политика вызвала контратаку противников на том основании, что «на Манхэттене нет кризиса недвижимости розничной торговли» [17]. Однако не в пользу этого мнения свидетельствует эмиссия коммерческих ипотечных ценных бумаг (англ. commercial mortgage-backed securities, CMBS), которая составила 95,3 млрд. долл. США по сравнению с 76 млрд. долл. США в 2016 г., что превзошло ожидания многих участников этого рынка. В 2019 г. ожидается аналогичная ситуация, где розничная торговля остается наиболее «тревожным» сектором среди всех залоговых типов недвижимости, поскольку по ним агентство «Фитч» (англ. Fitch) прогнозирует негативный рейтинг с низкой оценкой по многим траншам, которые будут проверены по мере приближения сроков погашения кредитов [25].

В целом мы полагаем, что закрытие магазинов традиционного торгового формата обусловлено несколькими причинами: во-первых, чрезмерно выросшей на последнее время арендной платой за торговую недвижимость на Пятой авеню, во-вторых, миграцией ритейла, стимулом для которой послужило увеличение за предыдущие годы объема доступных коммерческих площадей в Нью-Йорке, но все же основополагающей причиной закрытия магазинов традиционной розничной торговли является глобальный рост электронной коммерции в условиях развития цифровой экономики. Рассмотрим указанные причины.

I) Колебания стоимости аренды торговой недвижимости на Пятой авеню Манхэттена.

На Пятой авеню, между 49-й и 59-й улицами, осенью 2018 г. зафиксировано значительное снижение средней арендной ставки - на 24\% по сравнению с соответствующим показателем прошлого года, вследствие увеличения доступности и типов торговых площадей, предлагаемых в этой зоне [22].

По данным, представленным в Таблице 4, можно отметить общее снижение средней арендной ставки за период весна-осень 2018 г. по отношению к аналогичному периоду 2017 г.

По данным, представленным в Таблице 5, можно отметить общее падение средней арендной ставки “первых этажей” Пятой авеню за период весна-осень 2018 г. по отношению к аналогичному периоду 2017 г.

По данным, представленным в Таблице 6, можно судить о волатильности на рынке аренды 
Таблица 4. Колебание средней арендной ставки торговой недвижимости Пятой авеню по полугодиям за 2016-2018 гг.

\begin{tabular}{|c|c|c|c|c|c|c|c|c|}
\hline Субрынок & $\begin{array}{c}\text { Весна } \\
2015 \text { г. }\end{array}$ & $\begin{array}{c}\text { Осень } \\
2015 \text { г. }\end{array}$ & $\begin{array}{c}\text { Весна } \\
2016 \text { г. }\end{array}$ & $\begin{array}{c}\text { Осень } \\
2016 \text { г. }\end{array}$ & $\begin{array}{c}\text { Весна } \\
2017 \text { г. }\end{array}$ & $\begin{array}{c}\text { Осень } \\
2017 \text { г. }\end{array}$ & $\begin{array}{c}\text { Весна } \\
2018 \text { г. }\end{array}$ & $\begin{array}{c}\text { Осень } \\
2018 \text { г. }\end{array}$ \\
\hline Пятая авеню (42-49 улицы) & 435 & 510 & 447 & 390 & 348 & 384 & 360 & - \\
\hline Пятая авеню (49-59 улицы) & & 713 & 733 & 922 & 329 & 530 & 646 & 650 \\
\hline Пятая авеню - Парк авеню & & 1600 & 1600 & 1625 & 1438 & - & 1294 & 975 \\
\hline
\end{tabular}

Источник: составлена авторами на основании данных Совета по недвижимости Нью-Йорка (англ. The Real Estate board of New York) [22, 23]

Примечание: единицы измерения - долл. США за кв. фут.

Таблица 5. Колебание среднего значения арендной ставки за «первый этаж» аренды торговой недвижимости Пятой авеню за 2017-2018 гг.

\begin{tabular}{|c|c|c|c|c|c|}
\hline Субрынок & Осень 2017 г. & Весна 2018 г. & Осень 2018 г. & $\begin{array}{c}\text { Колебание } \\
\text { осень-весна } \\
2018 \text { г. (\%) }\end{array}$ & $\begin{array}{c}\text { Колебание } \\
\text { осень 2017 г.- } \\
\text { осень 2018 г. (\%) }\end{array}$ \\
\hline Пятая авеню (42-49 улицы) & 1158 & 1097 & 939 & -14 & -19 \\
\hline Пятая авеню (49-59 улицы) & 3900 & 3900 & 2973 & -24 & -24 \\
\hline Пятая авеню - Парк авеню & 1294 & 975 & 925 & -5 & -29 \\
\hline
\end{tabular}

Источник: составлена на основании данных Совета по недвижимости Нью-Йорка (англ. The Real Estate board of New York) $[22,23]$

Примечание: единицы измерения - долл. США за кв. фут.

Таблица 6. Колебание медианы арендной ставки за «первый этаж» торговой недвижимости Пятой авеню за 2017-2018 гг.

\begin{tabular}{|c|c|c|c|c|c|}
\hline Субрынок & Осень 2017 г. & Весна 2018 г. & Осень 2018 г. & $\begin{array}{c}\text { Колебание } \\
\text { осень-весна } \\
2018 \text { г. (\%) }\end{array}$ & $\begin{array}{c}\text { Колебание } \\
\text { осень 2017 г.- } \\
\text { осень 2018 г. (\%) }\end{array}$ \\
\hline Пятая авеню (42-49 улицы) & 909 & 1000 & 1200 & -9 & 24 \\
\hline Пятая авеню (49-59 улицы) & 2600 & 3900 & 3900 & -33 & -33 \\
\hline Пятая авеню - Парк авеню & 800 & 900 & 1250 & -11 & -36 \\
\hline
\end{tabular}

Источник: составлена авторами на основании данных Совета по недвижимости Нью-Йорка (англ. The Real Estate board of New York) $[22,23]$

Примечание: единицы измерения - долл. США за кв. фут.

Таблица 7. Динамика изменения стоимости средней арендной ставки субрынков торговых площадей Пятой Авеню г. Нью-Йорка за 2015-2018 гг.*

\begin{tabular}{|l|c|c|c|c|c|c|c|}
\hline \multicolumn{1}{|c|}{ Субрынок } & 2015 г. & 2016 г. & 2017 г. & $\begin{array}{c}1 \text { кв. } \\
2018 \text { г. }\end{array}$ & $\begin{array}{c}\text { 2 кв. } \\
2018 \text { г. }\end{array}$ & $\begin{array}{c}3 \text { кв. } \\
2018 \text { г. }\end{array}$ & $\begin{array}{c}4 \text { кв. } \\
2018 \text { г. }\end{array}$ \\
\hline Пятая авеню (от 42 до 49 улицы) & 1231 & & 1185 & 1160 & 1150 & 1006 & 996 \\
\hline Пятая авеню (расположение от 49 до 60 улицы) & 3095 & & 3123 & 2786 & 2775 & 2668 & 2668 \\
\hline $\begin{array}{l}\text { Пятая авеню (непосредственное расположение, } \\
\text { от 49 до 60 улицы) }\end{array}$ & 3370 & 3000 & 3188 & 2592 & 2694 & 2682 & 2682 \\
\hline
\end{tabular}

Источник: составлена автором на основании данных “Кушман энд Вэйкфилд” [6,13,14,15,24].

Примечание: единицы измерения - долл. США за кв. фут. в год (gross). 
торговой недвижимости, в результате которой арендодатели все чаще обращаются к брокерам с призывом снизить цены в предложениях на аренду принадлежащей им недвижимости с целью привлечения потенциальных арендаторов.

В Нью-Йорке наблюдается продолжение поиска ценового баланса спроса и предложения на аренду торговых площадей, при этом средняя арендная ставка, достигнув своего пика в 2018 г., продолжает снижаться. Как следствие, многие арендодатели поступают так, как этого требуют сложившиеся условия рынка,- снижают стоимость аренды, предлагают концессии и соглашаются на краткосрочную аренду, в то время как арендаторы, выгодно используют эти возможности, особенно в области реализации товаров продовольствия и одежды, а также фитнес индустрии [26].

II) Колебания объема строящихся коммерческих площадей в Нью-Йорке.

Объем строящихся коммерческих площадей в Нью-Йорке достиг своего пика за последние годы. В 2017 г. во многих ведущих городах США, где началось коммерческое и многоквартирное строительство, активность была ниже, чем в 2016 г. Объем коммерческого и многоквартирного строительства в национальном масштабе составил 194,7 млрд. долл. США, что на 7\% меньше, чем в 2016 г., в основном из-за снижения многоквартирного строительства, хотя он все еще был на 8\% выше, чем в 2015 г. Нью-Йорк, объем которого в 2017 г. составил 25,2 млрд. долл. США, продолжает оставаться ведущим рынком в США для начала строительства, хотя его объем сократился на 16\% по сравнению с 2016 г. [29]

Потенциальным фактором влияния на развитие и расширение рынка недвижимости (англ. Commercial real estate, CRE) является продолжающийся активный спрос со стороны неамериканских инвесторов. В целом рынок готов извлечь выгоду из этих потоков международных капитала, привлеченных текущей доходностью и повышенной прозрачностью рынка, усиленным экономическом ростом и надежными фун- даментальными принципами собственности США [30]. Однако история изменений в предпочтениях инвесторов и основах дохода, уникальна для каждого американского субрынка «CRE».

Отдельные особенности изменений рынка Манхэттена были замаскированы в последнем цикле весомыми изъятиями ликвидности из долевой части стека капитала. Перемены Манхэттенского рынка вызваны откатом интереса китайских инвесторов - не самого большого в доли участия, но основного в претензии на обладание значимыми активами Манхэттена. Присутствие этих участников торгов влияет на ценовые ожидания и развитие рынка в целом. Рынок «CRE» находится в подвешенном состоянии с падением объема сделок с начала 2017 г., поскольку покупатели и продавцы пытаются сформировать новый рыночный ландшафт, учитывая интересы его участников [31].

Таким образом, за последние два года объем рынка коммерческой недвижимости Нью-Йорка демонстрирует спад и, вряд ли, стал детерминантом в изменениях ритейла Пятой авеню.

III) Колебания показателей электронной коммерции.

С 2016 по 2017 гг. более 7 тыс. розничных магазинов было закрыто в США, что свидетельствует об увеличении этого показателя более, чем в три раза [32]. По состоянию на начало 2019 г. в Нью-Йорке по-прежнему все больше магазинов розничной торговли закрывается, чем открывается [33]. Такая тенденция вместе с изменением торговой структуры Пятой авеню отражает устойчивость тренда развивающейся цифровой экономики, в которой розничная торговля деградирует в свете акселерации онлайн-продаж [17].

Электронная торговля, несомненно, повлияла на важные элементы рынка в секторе розничной торговли: технологии, спрос и структуру [34]. По данным Министерства труда США, в 2015 г. ритейлеры 454 отрасли деятельности (англ. NAICS Industry 454), которая включает онлайнпокупки и покупки по каталогам, начали посте-

Таблица 8. Объем стартов строительства коммерческой и многоквартирной недвижимости за 2015-2017 гг.

\begin{tabular}{|c|c|c|c|c|c|}
\hline \multicolumn{1}{|c|}{ Субрынок } & $\begin{array}{c}2015 \text { г. } \\
\text { (млрд. долл. } \\
\text { США) }\end{array}$ & $\begin{array}{c}2016 \text { г. } \\
\text { (млрд. долл. } \\
\text { США) }\end{array}$ & $\begin{array}{c}2017 \text { г. } \\
\text { (млрд. долл. } \\
\text { США) }\end{array}$ & $\begin{array}{c}\text { Изменение } \\
2016 \text { г. к 2015 г. } \\
\text { (\%) }\end{array}$ & $\begin{array}{c}\text { Изменение } \\
2017 \text { г. к 2016 г. } \\
\text { (\%) }\end{array}$ \\
\hline $\begin{array}{l}\text { Нью-Йорк, Северный Нью- } \\
\text { Джерси - Лонг Айленд }\end{array}$ & 34868 & 29917 & 25221 & -14 & -16 \\
\hline
\end{tabular}

Источник: составлена авторами на основании данных «Додж дата энд аналитикс» [29]. 
пенно занимать все большую долю розничной торговле [35]. По сведениям, представленным в таблице 9, эта отрасль стремительно развивается и, вероятно, будет продолжать расширяться, поскольку онлайн-рынки растут и поглощают растущую долю общих розничных продаж.

По данным Бюро статистики Министерства торговли США, оценка розничных продаж электронной торговли в США за третий квартал 2018 г., с учетом сезонных колебаний, но без учета не изменения цен, составила 130,9 млрд. долл. США, увеличившись на $3,1 \%( \pm 0,5 \%)$ со второго квартала 2018 г. Общий объем розничных продаж за третий квартал 2018 г. оценивался в 1340,2 млрд. долл. США, увеличившись на $0,9 \%( \pm 0,2 \%)$ по сравнению со вторым кварталом 2018 г. Оценка электронной торговли в третьем квартале 2018 г. увеличилась 14,5\% ( 4,4\%) по сравнению с третьим кварталом 2017 г., в то время как общие розничные продажи выросли на $5,3 \%( \pm 1,4 \%)$ за тот же период. Продажи электронной коммерции в третьем квартале 2018 г. составили 9,8\% от общего объема продаж. Без учета корректировок, оценка розничных продаж электронной торговли в США в третьем квартале 2018 г. составила 121,5 млрд. долл. США, увеличившись на $0,8 \%$ ( $\pm 0,5 \%)$ по сравнению со вторым кварталом 2018 г. Оценка электронной торговли в третьем квартале 2018 г. увеличился на $14,3 \%( \pm 4,4 \%)$ по сравнению с третьим кварталом 2017 г., в то время как общий объем розничных продаж увеличился на $4,9 \%( \pm 1,4 \%)$ за тот же период. Продажи электронной коммерции в третьем квартале 2018 г. составили 9,1\% от общего объема продаж [36]. Данные представлены в таблице 10.

Рассмотренные причины, в той или иной степени, послужили основанием для наблюдаемых изменений торговой структуры на Пятой авеню. В результате, последнее время у розничных магазинов США и г. Нью-Йорка прослеживается оправданная тенденция оптимизации расходов на сокращении персонала и торговых площадей при переносе взаимодействия и коммуникаций с покупателями в цифровой формат взаимодействия. Также сегодня на рынке очень активны сети дисконтных магазинов (англ. off-price - формат розничных магазинов, предлагающих потребителям брендовые или дизайнерские товары по значительно более низким ценам, чем магазины со «стартовой» ценой») и ритейлеры гибридных форматов торгов- ли (англ. clicks-to-bricks).

В целом прослеживаются следующие изменения структуры ритейла на Пятой авеню:

- увеличение объема сдаваемых в аренду торговых площадей и снижение арендной платы привело к росту популярности временных магазинов (англ. pop-up - всплывающий) как возможности для арендодателей заполнить вакантные площади, хотя бы краткосрочной арендой;

- традиционная торговля переходит к модели выставочного зала, уменьшая товарный ассортимент и фокусируя свое внимание на повышении качества обслуживания и удовлетворенности спроса покупателей. Используя портативные электронные устройства, посетители магазина имеют возможность просматривать товары, где бы они ни хранились в зале, без необходимости физического их поиска. Это привело к тому, что некоторые розничные магазины уменьшают свои площади, поддерживают лимитированный товарный запас и отправляют покупки прямо со склада покупателям в короткие сроки;

- арендаторы ритейла переезжают и выбирают площадь ниже или выше первого этажа, пожертвовав привлечением пешеходов в угоду сокращению расходов на аренду. Например, некоторые магазины Манхеттена такие, как «Gap», «Old Navy Whole Foods», «Staples», «Modell'S» и «Duane Reade», выбрали такую стратегию [24];

- расширяется присутствие формата розничной торговли, совмещающего цифровые сервисы и традиционную торговлю [27]. Ввиду отсутствия соответствующего термина в отечественной научной литературе и адекватного перевода на русский язык, авторами предложено для него название «гибридный формат розничной торговли».

Если традиционная форма торговли (англ. brick-and-mortar - дослов. кирпич и цементный раствор) лишена интернет аудитории и не предлагает покупателям удобств цифровых сервисов при обслуживании в зале, то новая форма гибридной торговой бизнес-модели (англ. clicks-to-brick, «Womble Store Method» или Web Application Meets Bricks and Mortar) реализует как офлайн преимущества продаж (англ. bricks), так и интегрирует удобство цифровых сервисов и онлайн присутствия покупателей без привязки к территориальности расположения (англ. clicks).

Например, в мае 2017 г. «Амазон» (англ. 
Таблиц̧ 9. Оценка ежемесячного объема продаж в секторах 454 и 4541 розничной торговли и общественного питания США за 2017-2018 гг.

\begin{tabular}{|c|c|c|c|c|c|c|c|}
\hline \multirow[b]{2}{*}{ Отрасль деятельности } & \multicolumn{2}{|c|}{ Итого за 12 мес. } & \multicolumn{3}{|c|}{2018 г. } & \multicolumn{2}{|c|}{2017 г. } \\
\hline & 2018 г. & $\begin{array}{c}\text { \% изм. К } \\
2017 \text { г. }\end{array}$ & $\begin{array}{c}\text { дек. (a) } \\
\text { про- } \\
\text { гнози- } \\
\text { руемая } \\
\text { оценка }\end{array}$ & $\begin{array}{c}\text { нояб. (р) } \\
\text { пред- } \\
\text { вари- } \\
\text { тельная } \\
\text { оценка }\end{array}$ & $\begin{array}{l}\text { окт. (r) } \\
\text { уточ- } \\
\text { ненная } \\
\text { оценка }\end{array}$ & дек. & нояб. \\
\hline $\begin{array}{l}\text { 454. Розничная торговля, осущест- } \\
\text { вляемая без физической торговой } \\
\text { точки (англ nonstore retailer) }\end{array}$ & 678786 & 9,6 & 76960 & 69805 & 56911 & 74619 & 61933 \\
\hline $\begin{array}{l}\text { 4541. Электронная коммерция и } \\
\text { продажа товаров с доставкой на } \\
\text { дом (англ. electronic Shopping and } \\
\text { Mail-Order Houses) }\end{array}$ & $(*)$ & $(*)$ & $(*)$ & 62545 & 50157 & 66981 & 55156 \\
\hline
\end{tabular}

Источник: составлена авторами на основании данных Бюро статистики США (англ. Bureau of the Census) [16]. Примечание: данные представлены без учета сезонных колебаний и календарных смещений праздничных дней. Единицы измерения -млн. долл. США

Таблица 10. Оценка ежеквартального объема розничных продаж в США: розничная торговля и электронная коммерция

\begin{tabular}{|c|c|c|c|c|c|c|c|}
\hline \multirow{2}{*}{ Квартал } & \multicolumn{2}{|c|}{ Розничная торговля } & \multirow{2}{*}{$\begin{array}{c}\text { Электронная } \\
\text { коммерция, } \\
\text { процентное } \\
\text { отношение } \\
\text { к общему } \\
\text { показателю } \\
\\
\text { (\%) }\end{array}$} & \multicolumn{2}{|c|}{$\begin{array}{c}\text { Процентное измене- } \\
\text { ние к предыдущему } \\
\text { кварталу }\end{array}$} & \multicolumn{2}{|c|}{$\begin{array}{c}\text { Процентное изменение } \\
\text { к аналогичному квар- } \\
\text { талу предыдущего года }\end{array}$} \\
\hline & $\begin{array}{l}\text { Всего } \\
\text { (млн. } \\
\text { долл. } \\
\text { США) }\end{array}$ & $\begin{array}{c}\text { Эл. ком- } \\
\text { мерция } \\
\text { (млн. } \\
\text { долл. } \\
\text { США) }\end{array}$ & & $\begin{array}{c}\text { Всего } \\
(\%)\end{array}$ & $\begin{array}{l}\text { Эл. ком- } \\
\text { мерция } \\
\text { (\%) }\end{array}$ & $\begin{array}{c}\text { Всего } \\
(\%)\end{array}$ & $\begin{array}{l}\text { Эл. ком- } \\
\text { мерция } \\
\text { (\%) }\end{array}$ \\
\hline $\begin{array}{l}3 \text { кв. } 2018 \text { (р) } \\
\text { предварительная } \\
\text { оценка }\end{array}$ & 1340207 & 130946 & 9,8 & 0,9 & 3,1 & 5,3 & 14,5 \\
\hline $\begin{array}{l}2 \text { кв. } 2018 \text { (r) } \\
\text { уточненная оценка }\end{array}$ & 1328094 & 126985 & 9,6 & 1,6 & 3,6 & 5,7 & 14,9 \\
\hline 1 кв. 2018 & 1307255 & 122526 & 9,4 & 0,3 & 3,6 & 4,7 & 16,3 \\
\hline 4 кв. 2017 & 1303390 & 118216 & 9,1 & 2,4 & 3,4 & 5,9 & 16,6 \\
\hline $\begin{array}{l}3 \text { кв. } 2017 \text { (r) } \\
\text { уточненная оценка }\end{array}$ & 1272357 & 114333 & 9,0 & 1,2 & 3,5 & 4,6 & 15,7 \\
\hline 2 кв. 2017 & 1256659 & 110505 & 8,8 & 0,7 & 4,9 & 4,2 & 15,5 \\
\hline 1 кв. 2017 & 1248299 & 105387 & 8,4 & 1,5 & 3,9 & 5,0 & 14,4 \\
\hline 4 кв. 2016 & 1230389 & 101402 & 8,2 & 1,1 & 2,6 & 3,5 & 14,0 \\
\hline 3 кв. 2016 & 1216704 & 98858 & 8,1 & 0,9 & 3,4 & 2,1 & 14,5 \\
\hline 2 кв. 2016 & 1205521 & 95644 & 7,9 & 1,4 & 3,8 & 2,1 & 14,8 \\
\hline 1 кв. 2016 & 1188935 & 92145 & 7,8 & 0,0 & 3,6 & 2,5 & 14,5 \\
\hline 4 кв. 2015 & 1189054 & 88913 & 7,5 & $-0,2$ & 3,0 & 1,6 & 14,3 \\
\hline 3 кв. 2015 & 1191816 & 86335 & 7,2 & 1,0 & 3,6 & 1,9 & 13,9 \\
\hline
\end{tabular}

Источник: составлена авторами на основании данных Бюро статистики США (англ. Bureau of the Census)[37].

Примечание № 1: данные представлены с учетом сезонных колебаний и переноса праздничных дней, но без учета изменения цен.

Примечание № 2: в данной статистической выборке под электронной коммерцией рассматривается продажа товаров и услуг, при размещении или согласовании цены и условий заказа покупателем через Интернет, Экстранет, сеть электронного обмена данными (англ. EDI), электронную почту или другие онлайн системы. Оплата может быть, как произведена онлайн, так и в другой форме. 
Amazon) запустил свой первый книжный магазин на Манхеттене, предлагая посетителям ту информации о товаре, которая эффективно помогает им совершать покупки онлайн, а также оплату с помощью аккаунта Амазон и привязанной к нему кредитной картой [24]. Другой пример, это новый флагман «Найк Хаус оф Инновейшен 000» (англ. Nike House of Innovation 000) на Пятой авеню, который предлагает покупателям использовать смартфон для резервирования размеров обуви. Выбранные стили помещаются в специальный шкафчик, который затем разблокируется с помощью смартфона, а нужные товары могут быть отсканированы и мгновенно оплачены с помощью счета клиента «Nike Plus», минуя традиционный шаг поиска кассира и ожидания в очереди. Для «Nike» мобильные технологии обеспечивают преимущества гибридного торгового формата: оптимизированный сервис и дополнительную информацию о продукте в режиме онлайн, а также определенные преимущества офлайн - примерку товаров и их мгновенную покупку. К слову, успех гибридного формата торговли во многих секторах снизил доверие к прогнозам аналитиков, утверждавших, что интернет сделает традиционный ритейл устаревшим из-за дезинтермедиации [28].

Заключение. По результатам проведенного исследования можно сделать вывод о том, что позитивные показатели занятости населения, розничной и электронной торговли США, а также здоровая макроэкономическая среда г. Нью-Йорка в целом позволяют сделать оптимистичный прогноз о развитии ритейла в независимости от его формы. Ожидается, что туризм, вместе с ростом уровня занятости и увеличением среднего дохода на душу населения, будут стимулировать торговую активность розничной торговли на Пятой Авеню [6]. Вполне вероятно, что миграция ритейла продолжится в чертах города и спрос на самые дорогие субрынки будет сохраняться только у тех магазинов, покупатели которых менее всего ориентированы на переход к онлайн - покупкам. Однако, мы считаем, что в целом это вряд ли поможет прекратить тенденцию закрытия розничных магазинов традиционного «офлайн» формата.

Полагаем, что «кризис недвижимости ритейла Пятой авеню, пустующей без арендаторов» не может быть разрешен путем государственной интервенции: введения политики регулирования арендной платы или других муниципальных протекционных мер, поскольку пути его решения лежат в поле поиска адекватного ответа на современные вызовы развития рыночной конкуренции, формирующейся, в первую очередь, посредством влияния цифровизации общества и экономики. В этой связи любое искусственное вмешательство нанесет вред в естественный эволюционный отбор и процессы трансформации рынка розничной торговли.

Закрытие физических магазинов, на самом деле, не является апокалипсисом розничной торговли. Этот тренд больше похож на трансформацию ритейла в сторону развития новых и интересных концепций не только на улицах Манхэттена, но и в будущем глобально за его пределами. Об этом свидетельствует изменение торговой структуры Пятой авеню и развитие гибридных форматов торговли. Становится очевидным, что чем быстрее будут совершенствоваться технологии и активнее внедряться инновации в этом секторе, тем скорее покупатели смогут пользоваться преимуществами новых форматов розничной торговли, в существование и развитие которых в настоящее время пока еще трудно поверить. В этой связи будущее розничной торговли сегодня видится сложным для одних ритейлеров, не способных адекватно адаптироваться к меняющимся вкусам и потребностям цифрового общества, и «terra incognita», состоящей из новых возможностей и открытий для других.

На современном этапе развития американского общества не возникает никаких сомнений, что процесс цифровизации - внедрения и использования цифровой информации и цифровых услуг - имеет большое значение для социального и экономического развития экономики страны. Однако, как мы видим, цифровизация отдельных отраслей и предприятий в целом создает не только условия для достижения высоких социально-экономических результатов США, но и одновременно формирует ряд аспектов исключительного внимания на национальном, peгиональном и городском уровнях.

Рекомендации. Дальнейшее изучение вопроса развития гибридных форматов торговли, со стороны исследователей и практиков отечественного рынка, видится крайне важным, дабы предотвратить вызовы и угрозы, возникающие с развитием цифровизации ритейла, и адекватно имплементировать накопленный положительный опыт США в его решении. 


\section{Библиографический список}

1. Hortaçsu A., Syvers C. The Ongoing Evolution of US Retail: A Format Tug-of-War//Journal of Economic Perspectives. Fall 2015. Vol. 29(4). P. 90

2. Retail apocalypse [электронный ресурс]/ wikipedia.org: свободная энциклопедия [Википедиа.орг] URL: https://en.wikipedia.org/wiki/Retail_apocalypse (дата обращения 24.02.2019).

3. Hortaçsu A., Syvers C. The Ongoing Evolution of US Retail: A Format Tug-of-War// Journal of Economic Perspectives. Fall 2015. Vol. 29(4). P. 89-112.

4. Mastercard SpendingPulse: U.S. Retail Sales Grew 5.1 Percent This Holiday Season [электронный ресурс] / mastercard.com: official site [мастерцард.цом] URL: https://newsroom.mastercard.com/press-releases/ mastercard-spendingpulse-u-s-retail-sales-grew-5-1-percent-this-Wikipedia.orgholiday-season/ (дата обращения - 25.02.2019).

5. Main streets across the world 2018 [электронный pecypc] / cushmanwakefield.com [цушманщакефиелд.цом] URL: http://www.cushmanwakefield.com/en/research-and-insight/2018/main-streets-across-the-world-2018 (дата обращения 21.02.2019).

6. Manhattan Americas MarketBeat Retail Q42018 [электронный ресурс] / cushmanwakefield.com [цушманщакефиелд.цом].-2018.- URL: http://www.cushmanwakefield.com/en/research-and-insight/unitedstates/ manhattan-retail-snapshot (дата обращения 21.02.2019)

7. Economic Snapshot - Volume 1, 2019 [электронный ресурс] / nycedc.com [ныцедц.цом].-2018. - URL: https:// www.nycedc.com/economic-data/economic-snapshot-volume-1-2019 (дата обращения 21.02.2019).

8. Economic Snapshot - Volume 12, 2018 [электронный pecypc] / nycedc.com [ныцедц.цом].-2018. - URL: https:// www.nycedc.com/economic-data/economic-snapshot-volume-12-2018 (дата обращения 21.02.2019).

9. Manhattan Americas MarketBeat Office.Q1.2018 [электронный ресурс] / cushmanwakefield.com [цушманщакефиелд.цом].-2018.- URL: http://www.cushmanwakefield.com/en/research-and-insight/unitedstates/ manhattan-office-snapshot (дата обращения 21.02.2019).

10. Manhattan Americas MarketBeat Office.Q2.2018 [электронный ресурс] / cushmanwakefield.com [цушманщакефиелд.цом].-2018. - URL: https://www.nycedc.com/economic-data/economic-snapshot-volume-12-2018 (дата обращения 21.02.2019).

11. Manhattan Americas MarketBeat Office.Q3.2018 [электронный ресурс] / cushmanwakefield.com [цушманщакефиелд.цом].-2018. - URL: https://www.nycedc.com/economic-data/economic-snapshot-volume-12-2018 (дата обращения 21.02.2019).

12. Manhattan Americas MarketBeat Office.Q4.2018 [электронный ресурс] / cushmanwakefield.com [цушманщакефиелд.цом].-2018. - URL: https://www.nycedc.com/economic-data/economic-snapshot-volume-12-2018 (дата обращения 21.02.2019).

13. Manhattan Americas MarketBeat Retail Q1 2018 [электронный ресурс] / cushmanwakefield.com [цушманщакефиелд.цом].-2018. - URL: http://www.cushmanwakefield.com/en/research-and-insight/unitedstates/ manhattan-retail-snapshot (дата обращения 21.02.2019).

14. Manhattan Americas MarketBeat Retail Q2 2018 [электронный ресурс] / cushmanwakefield.com [цушманщакефиелд.цом].-2018.- URL: http://www.cushmanwakefield.com/en/research-and-insight/unitedstates/ manhattan-retail-snapshot (дата обращения 21.02.2019).

15. Manhattan Americas MarketBeat Retail Q3 2018 [электронный ресурс] / cushmanwakefield.com [цушманщакефиелд.цом].-2018.- URL: http://www.cushmanwakefield.com/en/research-and-insight/unitedstates/ manhattan-retail-snapshot (дата обращения 21.02.2019).

16. Estimated Measures of Sampling Variability for Monthly Estimates by Kind of Business: 2018/ census. gov: оф. сайт Бюро статистики США [ценсус.гов].-2018. - URL: https://www.census.gov/retail/mrts/www/benchmark/2018/ html/annrev18.html (дата обращения 04.02.2019).

17. Gap's Fifth Ave. store closure is a bad sign for NYC retail scene [электронный ресурс] // NY Post [НЙ Пост].2018. - URL: https://nypost.com/2018/12/25/gaps-fifth-ave-store-closure-is-a-bad-sign-for-nyc-retail-scene/ (дата обращения 04.02.2019).

18. Retail Mid-Q42018 [электронный ресурс] / absre.com [абсре.цом].-2018.- URL: https://absre.com/research/ (дата обращения 21.02.2019). 
19. Lord \& Taylor flagship store locks its doors forever [электронный ресурс] // Associated Press: нов. агенство [Асоушиэтид Пресс]. 2019. URL: https://www.apnews.com/726556591dfb46049dd7d7f98de47da5 (дата обращения 04.02.2019).

20. Kilgannon C. This Space Available [электронный ресурс]// nytimes.com: нов. агенство [нытимес.цом].-2018.URL: https://www.nytimes.com/interactive/2018/09/06/nyregion/nyc-storefront-vacancy.html. (дата обращения 04.02.2019).

21. Saxe B., Dockwel B. Commercial Rent Control: Back Again? [электронный ресурс]// law.com [лащ. цом] -2018.-URL: https://www.law.com/newyorklawjournal/2018/11/28/commercial-rent-control-backagain/?slreturn=20190123154508 (дата обращения 04.02.2019).

22. Fall 2018 Manhattan Retail Report [электронный ресурс]/ rebny.com [ребны.цом] -2018.-URL: REBNY_ Manhattan_Retail_Report_Fall_2018_ https:/www.rebny.com/content/rebny/en/research/retail/Fall_2018_ Manhattan_Retail_Report.html (дата обращения 04.02.2019).

23. REBNY_Manhattan_Retail_Report_Spring_2018 [электронный ресурс]// rebny.com [ребны.цом] .-2018.-URL: https://www.rebny.com/content/rebny/en/research/retail/Spring_2018_Manhattan_Retail_Report.html (дата обращения 04.02.2019).

24. U.S. Brick-And-Mortar Retail Decline Hits New York City [электронный ресурс]// bisnow.сот [биснощ.цом] .-2017.-URL: https://www.bisnow.com/new-york/news/commercial-real-estate/anchin-nyc-update-74494?utm source=CopyShare\&utm_medium=Browser (дата обращения 04.02.2019).

25. Cunnungham C. Rating Agency Mavens Weigh in on What 2019 Holds in Store for CMBS [электронный ресурс]/ commercialobserver.com [цоммерциалобсервер.цом].-2018.URL: https://commercialobserver.com/2018/12/ rating-agency-cmbs-predictions/ (дата обращения 04.02.2019).

26. CBRE Releases Q12018 Manhattan Retail Report [электронный pecypc]// cbre.us [цбре.yc].-2018.URL: https://www.cbre.us/about/media-center/cbre-releases-q1-2018-manhattan-retail-report. (дата обращения 04.02.2019).

27. Bricks and clicks [электронный ресурс]// wikipedia.org wikipedia.org: свободная энциклопедия [щикипедиа. орг].-2018.-URL: https://en.wikipedia.org/wiki/Bricks_and_clicks (дата обращения 04.02.2019).

28. Bricks and clicks [электронный ресурс]// revolvy.com [револвы.цом].-2014.-URL: https://www.revolvy.com/ page/Bricks-and-clicks. (дата обращения 04.02.2019).

29. Dodge date and analytics [электронный ресурс]// construction.com [цонструцтион.цом].-2018.-URL: https:// www.construction.com. (дата обращения 04.02.2019).

30. A Productive 2017 for CRE; More of the Same for 2018? [электронный ресурс]/ commercialobserver.com [цоммерциалобсервер.цом].-2017.-URL: https://commercialobserver.com/2018/01/a-productive-2017-for-cre-moreof-the-same-for-2018/. (дата обращения 04.02.2019).

31. Costello J. Manhattan Commercial Prices Dance to Own Tune [электронный ресурс]/ rcanalytics.com [рцаналытицс.цом].-2018.-URL: https://www.rcanalytics.com/manhattan-prices-dance-own-tune/ (дата обращения 04.02.2019).

32. Helm S., Kim S.H., Van Riper S. Navigating the "retail apocalypse": A framework of consumer evaluations of the new retail landscape // Journal of Retailing and Consumer Services. -2018._ DOI: 10.1016/j.jretconser.2018.09.015

33. January 2019 New York Commercial Real Estate Market Repor [электронный ресурс]/ optimalspaces.com [oптималспацес.цом].-2019.-URL: https://www.optimalspaces.com/january-2019-new-york-office-market-report/ (дата обращения 04.02.2019).

34. Lieber E., Syverson C. Online versus Offline Competition// In Oxford Handbook of the Digital Economy, ed. by Peitz M., Waldfogel J. Oxford University Press. - 2012.-pp. 189-223.

35. Significant Industries: A Report to the Workforce Development System. New York City 2015/labor.ny.gov: oф. caйт New York State Department of Labor [лабор.ны.гов].-2015.-URL: https://labor.ny.gov/stats/PDFs/SignificantIndustries-New-York-City.pdf. (дата обращения 04.02.2019).

36. QUARTERLY RETAIL E-COMMERCE SALES3rd QUARTER2018 / census.gov: оф. сайт Бюро статистики СШA [ценсус.гов].-2018. - URL: https://www.census.gov/retail/mrts/www/data/pdf/ec_current.pdf (дата обращения 04.02.2019).

37. Estimated Quarterly U.S. Retail Sales (Adjusted): Total and E-commerce/ census.gov: оф. сайт Бюро статистики США [ценсус.гов].-2018.- URL: https://www.census.gov/retail/index.html (дата обращения 04.02.2019). 